\title{
Odmienność narodowa i etniczna w najnowszej polskiej literaturze dla młodego odbiorcy a wyzwania edukacji międzykulturowej
}

\begin{abstract}
Children's literature plays a key role in the process of socialization. It is one of the crucial factors which help the young reader to understand the surrounding world, also in terms of what is one's own and what is other, different. On the one hand, its task is reflecting the existing reality, on the other - shaping specific attitudes towards it, for example through strengthening existing stereotypes or calling them in question. In English-language literature on the subject one can find numerous analyses of both broadly understood intercultural literature and depictions of individual nationalities, cultures, and races. So far, Polish children's literature has not attracted much scholarly attention in this respect. It might result from the fact that the Polish population is to a large extent a homogenous group as regards race and nationality. However, this state of affairs is gradually changing, as Poland starts to attract migrants from all over the world and national and ethnic minorities already inhabiting the country are being discovered. In this context, it seems particularly interesting to ask if and how these social changes have influenced Polish children's literature of today. The goal
\end{abstract}

\footnotetext{
${ }^{1}$ Anna Fornalczyk-Lipska, Instytut Lingwistyki Stosowanej, Uniwersytet Warszawski, Polska, a.fornalczyk@uw.edu.pl.
} 
of this paper is to outline the issue of cultural diversity, in particular the presence of the national and ethnic "other" in the newest Polish children's literature, according to criteria developed on the basis of Short, LynchBrown and Tomlinson's guidelines (2014). The paper is also an attempt at determining to what extent Polish children's literature corresponds with the model of intercultural education. As the analysis shows, Polish literature on cultural diversity is scarce, involves non-representative depictions of minorities, and lacks the "insider" perspective, and thus fulfills the postulates of intercultural education only in a limited way.

\section{Keywords:}

Polish children's literature, Polish young adult literature, intercultural education, cultural diversity, the national-ethnic other

\section{LITERATURA DZIECIĘCA W KONTEKŚCIE WIELO- I MIĘDZYKULTUROWOŚCI}

Literatura dziecięca należy zarówno do systemu literackiego, jak i edukacyjnego (Shavit, 1994, s. 4). Z założenia jest narzędziem pedagogiki, gdyż przekazuje czytelnikom określoną wizję świata, kształtuje ich świadomość i pożądane postawy, a jednocześnie wiele mówi o społeczeństwie, w którym powstała i do którego wychowuje. Łączy w sobie dydaktyzm i artyzm, kształtując młodego czytelnika także pod względem estetycznym, odwołując się do jego przemyśleń i uczuć, uruchamiając mechanizm identyfikacji z bohaterami. By była atrakcyjna dla młodego odbiorcy, powinna uwzględniać m.in. współczesny kontekst polityczno-społeczny.

Niewątpliwie jedną z ważniejszych przemian ostatnich kilku dekad jest rosnąca liczba obcokrajowców. Polska stopniowo staje się krajem przyciągającym imigrantów z różnych stron świata, reprezentantów różnorodnych narodowości, kultur i ras. Jednocześnie na nowo „odkrywa się” już zamieszkujące Polskę mniejszości narodowe i etniczne. W tej sytuacji pojawia się pytanie, czy współczesna literatura dla młodego odbiorcy uwzględnia te przemiany i - jeśli tak - w jaki sposób przedstawia odmienność narodowo-etniczną.

W opisie sytuacji zróżnicowania kulturowego pomocne mogą być definicje wielo- i międzykulturowości. Kategoria wielokulturowej literatury dziecięcej powstała w Stanach Zjednoczonych w latach 60. XX wieku w związku z przemianami społecznymi. Wtedy to pedagodzy i badacze zaczęli zwracać uwagę na niereprezentatywny oraz nadmiernie uproszczony obraz czarnoskórych Amery- 
kanów w literaturze dziecięcej, nacechowany wykluczeniem oraz stereotypizacją (por. kluczowy artykuł Nancy Larrick z roku 1965 pt.: „The All-White World of Children’s Books” [Zupełnie biały świat książek dla dzieci, tłum. AFL]). Dzięki naciskowi innych grup doświadczających rasistowskiego traktowania i domagających się uwzględnienia swojej odmienności w programach szkolnych, zaczęły powstawać w dużych ilościach nowe materiały poświęcone grupom etnicznym reprezentującym inne niż biała rasy (Botelho, Kabakow Rudman, 2009, s. 74). Zaangażowanie wydawców, naukowców i pedagogów sprawiło, że kategoria wielokulturowej literatury dziecięcej rozpowszechniła się pod koniec lat 80. XX wieku, obejmując głównie kategorie rasowe i etniczne, a w połowie lat 90. poszerzono ją o kwestie związane z płcią (gender), klasą społeczną, orientacją seksualną, (nie)pełnosprawnością, wiekiem, religią itd.

W kompleksowym opracowaniu literatury dziecięcej pod redakcją Short, Lynch-Brown i Tomlinsona (2014, s. 218) znajdujemy następującą definicję literatury wielokulturowej (multicultural literature): literatura wielokulturowa jest najczęściej rozumiana jako literatura poświęcona grupom zmarginalizowanym przez dominującą europejsko-amerykańską kulturę w USA lub jako literatura pisana przez przedstawicieli grup zmarginalizowanych. Definicja obejmuje mniejszości rasowe, etniczne, religijne i językowe, osoby niepełnosprawne, o innej orientacji seksualnej, ubogie (o niskim statusie społecznym). Autorzy opracowania wyróżniają także literaturę międzynarodową (international literature) obejmującą książki, których akcja dzieje się w krajach poza USA, napisane pierwotnie dla dzieci mieszkających w tych krajach, oraz literaturę globalną (global literature), napisaną i opublikowaną w USA dla dzieci amerykańskich, ale osadzoną w kontekście międzynarodowym.

Inni autorzy (Pratt, 1999, s. 2) wyróżniają kategorię literatury transkulturowej jest to pojęcie względne, definiowane z perspektywy odbiorcy, i obejmuje książki poświęcone kulturom spoza kraju czytelnika.

Jeszcze inny podział proponują Cai i Bishop (1994), wyróżniając trzy kategorie literatury wielokulturowej: literatura światowa, międzykulturowa i kultur równoległych (odpowiednio: world literature, cross-cultural literature, parallel culture literature). W pewnym uproszczeniu, pierwsza kategoria miałaby obejmować książki na temat grup zamieszkałych poza Stanami Zjednoczonymi, druga - dzieła traktujące o wzajemnych relacjach przedstawicieli różnych kultur, trzecia natomiast - literaturę autorstwa przedstawicieli kultur równoległych na temat ich własnej kultury. Bez wątpienia ta ostatnia kategoria, jako najpełniej reprezentująca doświadczenie kulturowe danej grupy, najlepiej służy celom edukacji wielokulturowej (Botelho, Kabakow Rudman, 2009, s. 82). 
W anglojęzycznej literaturze przedmiotu występuje odwołanie do wielokulturowości rozumianej opisowo, jako wielość kultur, często jednak ma ona znaczenie nacechowane, gdyż głównym zadaniem edukacji wielokulturowej jest asymilowanie mniejszości ze społeczeństwem i zaznajamianie ich z kulturą, historią i językiem społeczności dominującej oraz wychowanie ku tolerancji i zapobieganie rasizmowi w celu zachowania społecznego spokoju i umożliwienia zgodnego współżycia w społeczeństwie wielokulturowym (Grzybowski, 2008, s. 56).

Na przełomie XX i XXI wieku w piśmiennictwie amerykańskim nastąpiła pewna ewolucja koncepcji wielokulturowości. Po zauważeniu, że skupienie na kategoriach rasowych doprowadziło do zaniedbania dynamiki skomplikowanych relacji społecznych wewnątrz i między grupami odmiennymi kulturowo, zaproponowano krytyczne podejście wielokulturowe (critical multicultural analysis). Polega ono na uwzględnieniu w nauczaniu i doborze literatury nie tylko specyfiki kulturowej poszczególnych grup, ale historycznego i socjopolitycznego kontekstu wzajemnych relacji, rozpatrywanych przede wszystkim z punktu widzenia władzy (w jaki sposób jest ona sprawowana, negocjowana, konstruowana, kto dominuje, a kto jest wykluczony itd. Botelho, Kabakow Rudman, 2009, s. 30), co zależy nie tylko od rasy, ale również klasy społecznej i płci.

W piśmiennictwie polskim spotyka się zarówno termin literatura wielokulturowa (np. Janus-Sitarz, 2014; Kamińska, 2005), jak i pojęcie literatury międzykulturowej (np. Niesporek-Szamburska, Wójcik-Dudek, 2014; Grzybowski, 2008). Niekiedy pojęcia te używane są zamiennie i traktowane jako synonimy (por. Janus-Sitarz, 2014 czy Niesporek-Szamburska, Wójcik-Dudek, 2014). Należy jednak je rozróżnić, gdyż podejście wielokulturowe i międzykulturowe zakorzenione są w odmiennej aksjologii. O ile to pierwsze odnosi się, jak już wyżej wspomniano, do ideologii mającej na celu umożliwienie mniejszościom uczestnictwa w kulturach narodowych na zasadzie asymilacji z grupą dominującą, o tyle podejście międzykulturowe zakłada możliwość stworzenia harmonii ponad różnicami w oparciu o dialog, a nie dominację jednej z grup. Różnica traktowana jest jako bogactwo, czynnik umożliwiający rozwój, integrację i dynamizację społeczeństwa, przy czym podkreśla się znaczenie jednostki. Choć nie istnieje jeden obowiązujący model edukacji międzykulturowej, a w jej ramach można wyróżnić wiele odmian, to wszystkie podkreślają wartość obu stykających się kultur i kładą nacisk na wzajemne poszanowanie i zrozumienie odmienności przy jednoczesnym uznaniu własnej odrębności i tożsamości. Jak pisze Grzybowski (2008, s. 64), do głównych celów edukacji międzykulturowej należy wyzbywanie się poczucia wyższości kulturowej, nacjonalizmów, uprzedzeń i stereotypów, a także rozumienie i poszanowanie odmienności kulturowej przy jednoczesnym docenieniu 
własnej tożsamości, odrębności, godności i wartości, poszukiwanie porozumienia poprzez interakcję, dialog i negocjacje. Dopełnieniem edukacji międzykulturowej są edukacja regionalna i edukacja obywatelska. Wg Kamińskiej (2005), celem edukacji międzykulturowej byłoby nie tylko poznawanie innej kultury, lecz uczenie się innegoz jednej strony kodu kulturowego i nabywanie określonej kompetencji kulturowej, pozwalającej, na ciągłe poszukiwanie podobieństw w dostrzeganych różnicach, a z drugiej na kreowanie nowej, wielowymiarowej płaszczyzny dialogu oraz osadzenie obcych kultur na w miarę obiektywnym i stabilnym podłożu (Kamińska, 2005).

Inspirację dla przygotowania niniejszego artykułu stanowiły rozmowy z nauczycielami i bibliotekarzami, którzy stykając się z odmiennością narodową i etniczną w swoim środowisku szkolnym, odczuwają brak książek przedstawiających tę problematykę. Owszem, są dostępne propozycje zagraniczne, tłumaczone na język polski, jednak nie uwzględniają one rodzimych realiów. Współczesna polska literatura dla dzieci i młodzieży poświęcona tematyce odmienności z pewnością byłaby cennym uzupełnieniem i ułatwieniem pracy dydaktycznej. W sytuacji zróżnicowania kulturowego literatura pozwala na doświadczenie wspólnoty przeżyć z dziećmi innych kultur, uświadamia nauczycielom i uczniom, co to znaczy być „obcym” czy „innym” narodowościowo. Poprzez przybliżenie innej kultury przygotowuje do kontaktu z odmiennością i w ten sposób wspiera obcokrajowców w aklimatyzacji. Jak pisze Anna Janus Sitarz (2014, s. 21), „[o]twartości wobec innych... uczyć można, sięgając po literaturę, która w sposób nieinstrumentalny, bez nachalnego dydaktyzmu i zniechęcającego patosu, ale sugestywnie mówi o potrzebie tolerancji, o groźbie nienawiści narodowej”. Podobnie jak specjalne programy edukacyjne, muzyka, sztuka, teatr czy film, również odpowiednio dobrana literatura pomaga w kształceniu takiego podejścia wobec Innego, dlatego może być wykorzystana w edukacji międzykulturowej.

\section{ODMIENNOŚĆ NARODOWA I ETNICZNA W LITERATURZE DZIECIĘCEJ}

Celem artykułu jest przegląd współczesnej polskiej literatury dziecięcej z ostatnich 15 lat, poświęconej przedstawicielom innych narodowości. Skupię się na literaturze pięknej - powieściach i zbiorach opowiadań, pomijając książki o charakterze popularnonaukowym, prezentującym fakty o danym państwie. Nie neguję niewątpliwej wartości tych ostatnich, jako że przyczyniają się one do wzrostu wiedzy o poszczególnych krajach, jednak nie są w stanie odwołać się do emocjonalności odbiorcy, pokazać innego sposobu myślenia i odczuwania, a tym samym aktywnie 
kształtować postaw wobec odmienności w taki sposób, jak może to czynić literatura piękna. Obecność Innego zostanie przeanalizowana wg kryteriów opracowanych w oparciu o propozycję Short i in. (2014, s. 220-222), uwzględniając aspekty takie jak: reprezentowane grupy narodowościowe, problematyka książek, zachowanie autentyczności kulturowej, występowanie stereotypów dotyczących poszczególnych grup ${ }^{2}$, wielowymiarowość przedstawienia danej kultury, perspektywa narracji, relacje między bohaterami odmiennymi kulturowo oraz zamierzony odbiorca.

O ile w niektórych krajach dokonuje się bieżących analiz określających procent książek przedstawiających zróżnicowanych rasowo czy narodowościowo bohaterów (np. w USA zajmuje się tym Cooperative Children's Book Center), to w Polsce takich statystyk się nie prowadzi. Być może spowodowane jest to dość jednorodną strukturą ludności Polski, która wg danych GUS-u z roku 2011 obejmuje przede wszystkim populację o polskich identyfikacjach narodowościowych (37 mln 394 tys., czyli 97,1\% ogółu mieszkańców Polski). Wśród pozostałych, nie-polskich identyfikacji (dotyczących prawie 1 mln 468 tys. osób, czyli 3,8\% ludności) dominują niemiecka, ukraińska, białoruska i romska (źródło: Struktura narodowo-etniczna, językowa i wyznaniowa ludności Polski, 2015).

Choć za początki wielokulturowej literatury dziecięcej uznaje się lata 60, to problem zróżnicowania kulturowego poruszano już znacznie wcześniej. Wystarczy wspomnieć przypadające na lata przedwojenne paralelne względem siebie powieści Janusza Korczaka opisujące codzienne życie dzieci na koloniach letnich: Mośki, Joski i Srule oraz Józki, Jaśki i Franki (wspomina o tym Wróblewska, 2013), które ukazując przykład analogicznych wydarzeń miały na celu podkreślenie uniwersalności zachowań i przeżyć dzieci przy jednoczesnym pokazaniu odmienności kultury polskiej i żydowskiej.

Szczególną uwagę zwraca cała grupa książek poświęconych jednej określonej mniejszości i to w konkretnym przedziale czasowym. Chodzi mianowicie o książki opowiadające o gettach żydowskich w czasie II wojny światowej. W 2012 roku roku Korczakowskim - pojawiła się znaczna liczba książek poświęconych tej tematyce 3 , na przykład: Kotka Brygidy Joanny Rudniańskiej (2007), Bezsenność Jutki Combrzyńskiej-Nogali (2012) czy Pamiętnik Blumki Iwony Chmielewskiej (2011). Jest to głównie proza historyczna, a więc nie odzwierciedla obecnej sytuacji w Polsce, a jej analiza wykracza poza ramy niniejszego tekstu.

${ }^{2}$ Wg definicji Słownika języka polskiego (http://sjp.pl/stereotypie), stereotyp to „uproszczony obraz kogoś lub czegoś, zwykle oparty na częściowo fałszywych sądach, funkcjonujący w świadomości społecznej i niełatwo zmieniający się”.

${ }^{3}$ Za tę uwagę dziękuję Annie Marii Czernow. Pragnę też podziękować Pracownikom Muzeum Książki Dziecięcej w Warszawie za pomoc w dotarciu do niektórych omawianych tu źródeł. 
Jeśli chodzi o polską literaturę dziecięcą poruszającą problem obcości narodowej i etnicznej w realiach XXI wieku, to jest ona dość nieliczna i rozproszona. Kwerenda biblioteczna przeprowadzona w zbiorach warszawskiego Muzeum Książki Dziecięcej oraz Bibliotece Narodowej pozwoliła na dotarcie do zaledwie jedenastu pozycji (zostały one wymienione w bibliografii do niniejszego artykułu i będą omówione poniżej). Można by pokusić się o określenie procentowego udziału tych książek w całym zbiorze literatury dziecięcej dostępnej w Polsce, ale wobec braku prowadzonych w tym zakresie statystyk nie jest to możliwe. By jednak uzmysłowić czytelnikowi, jak niewielka jest to liczba, wspomnę, że samo Wydawnictwo Literatura, jeden z głównych wydawców książek dla dzieci i młodzieży, w swoim katalogu obejmującym jedno tylko półrocze ${ }^{4}$ wylicza ponad 250 pozycji rodzimych autorów. Wobec tego z pewnością warto przyjrzeć się dokładniej tym nielicznym książkom, w których problem obcości narodowej i etnicznej został osadzony we współczesnych polskich realiach.

Opowiadania dla młodszych dzieci, głównie przedszkolaków, przedstawiają odmienność posługując się motywem nowego/nowej w przedszkolu (Nowa w przedszkolu; Basia i kolega z Haiti; Przedszkolaki z ulicy Morelowej) lub towarzysza zabaw obcej narodowości (Opowiadania z piaskownicy; Kacper z szuflady; Zuzanka z pistacjowego domu). Zamierzonym odbiorcą książek jest polskie dziecko; pisane są także z perspektywy kogoś, kto jest częścią polskiej społeczności i spotyka osoby odmienne kulturowo. Reprezentowane narodowości/etniczności to - odpowiednio - Afrykanka (nazwa kraju, z którego pochodzi, nie została podana), Haitańczyk, Szwed, Chinka i Wietnamczyk (w dwóch ostatnich książkach). Niektóre opowiadania prezentują obcość w sposób epizodyczny, uproszczony, jednowymiarowy, ograniczony do podania obcych imion, wprowadzenia typowych elementów kultury czy podkreślenia „dziwnego” brzmienia obcego języka. W Opowiadaniach z piaskownicy narrator spotyka w piaskownicy małą Chinkę, Mayumi, i określa wypowiadane przez nią po chińsku kwestie jako „zgrzytanie łyżwy po lodzie” i „odgłos przypominający serię wystrzałów z kulkowca” (Piątkowska, 2015, s. 75, 76). Ciekawe jest też przedstawienie nieco naiwnego, dziecięcego podejścia do inności, zrównującej polskość z „normalnością” - bohater Renaty Piątkowskiej nie potrafi ukryć zdziwienia, że jego chińska koleżanka „zaśmiała się całkiem normalnie, po polsku” i że robiła „całkiem zwyczajne, polskie babki” (Piątkowska, 2015, s. 75). Obcy kulturowo bohater budzi w dzieciach przede wszystkim ogromną ciekawość, jest zasypywany pytaniami o kraj pochodzenia (por. „Gdzie jest ta Szwecja? Długo się tam jedzie? Co jecie na śniadanie? [...]

\footnotetext{
${ }^{4}$ Wydawnictwo Literatura. Katalog. Wiosna 2016.
} 
A naucys mnie cegoś po swecku?”, Gawryluk, 2013, s. 8), co umożliwia autorom książek zaprezentowanie niektórych realiów kulturowych, choć z konieczności w sposób skrótowy.

Nowa w przedszkolu oraz Basia i kolega z Haiti poświęcone są w całości problemowi odmienności. Ukazują pierwszy kontakt z Innym za pomocą przejścia od schematu Inny - Obcy - Wróg do schematu Inny - Interesujący - Przyjaciel. Kluczem do tej metamorfozy jest zrozumienie inności, inspirowane wyjaśnieniami i postawą osoby dorosłej (rodzica czy nauczyciela). Po rozmowie z dorosłym i poznaniu zarówno pewnych realiów obcej kultury, jak i osobistej historii Innego, następuje otwarcie się przedszkolaków na to, co inne, i akceptacja odmiennego kulturowo kolegi czy koleżanki. Prześladowanie odmienności ukazywane jest jako chuligański wybryk i ukarane, jak w Zuzance..., gdzie wietnamski bohater spotyka się z wyzwiskami i groźbami („,Te, żółtek! Co tu robisz? Po co się plączesz po naszym podwórku? [...] Nie bój się, żółtek, dasz pięć złotych i możesz iść do domu”, Gawryluk, 2009, s. 83).

Już w literaturze dla najmłodszych kwestionuje się istniejące stereotypy - czy to te dotyczące konkretnych narodowości, czy też te dotyczące obcokrajowców w ogóle. W Kacprze z szuflady tytułowy bohater cytuje sąsiada: „A pan Wredzik uważa, że [...] Polacy powinni trzymać z Polakami, a Wietnamczycy z Wietnamczykami. Bo jak tak dalej pójdzie, to obcokrajowcy zabiorą Polakom mieszkania i prace, a zamiast kościołów wszędzie będą budy z sajgonkami” (Kasdepke, 2013, s. 85). Podobne poglądy nie są pozostawione bez komentarza: tata Kacpra natychmiast dementuje posądzenia sąsiada, rzeczowo wyjaśniając synowi, że: „tata Tuana nie zabrał nikomu mieszkania, tylko je kupił. Pracy też nikogo nie pozbawił, przeciwnie, zatrudnił nawet panią Anię. To że nie chodzi do tego samego kościoła, co pan Wredzik, nie znaczy, że nie wierzy w Boga, ani - tym bardziej - że jest złym człowiekiem [...]. Pan Wredzik uważa, że wszyscy powinni być tacy jak on. Ale wyobrażasz sobie świat pełen Wredzików?” (Kasdepke, 2013, s. 85). Z kolei jeden z bohaterów Nowej w przedszkolu przytacza takie oto słowa rodzica na temat „obcych”: „mój tata mówi, że nie powinno się ufać obcym... a ona jest obca, przecież od razu widać. [...] Mój tata mówi, że każdy powinien mieszkać u siebie i nie zawracać głowy tym, że jest inny” (Pruchnicka, 20155). Obraz rzeczywistości przedstawiony przez chłopca miejscami ociera się o śmieszność, co stanowi dla czytelnika jasny sygnał, że nie może być brany na poważnie (,a wiecie, że w afrykańskich domach słonie i zebry wyjadają z lodówki banany?!”, Pruchnicka, 2015).

\footnotetext{
${ }^{5}$ Strony w książkach obrazkowych z reguły nie są numerowane.
} 
Podsumowując, przedstawienie odmienności kulturowej w literaturze dla najmłodszych charakteryzuje się pewną schematycznością i uproszczeniem, głównie ze względu na niewielką objętość książek. Jednocześnie jednak podkreślona jest wartość odmienności jako ubogacenia, kwestionuje się stereotypy i uprzedzenia, które dzieci najczęściej przejmują od dorosłych, a także promuje poszukiwanie porozumienia z Innym poprzez interakcję i dialog. Jak będzie przedstawiała się sytuacja w książkach dla młodzieży?

\section{ODMIENNOŚĆ NARODOWA I ETNICZNA W LITERATURZE MŁODZIEŻOWEJ}

Spośród książek dla młodszej młodzieży szkolnej warto wymienić Szczekajq̨cq szczękę Saszy (2005) Ewy Grętkiewicz, Majkę, Marcela i afrykańskie czary (2009) Katarzyny Szczepańskiej-Kowalczuk oraz Język Trolli (2004) Małgorzaty Musierowicz. Pierwsza z nich opisuje pobyt młodego Białorusina w polskiej szkole; druga przedstawia Sudańczyka Chojangę, nowego sąsiada głównej bohaterki; w trzeciej natomiast występuje (podobnie jak w poprzedniej pozycji - w charakterze bohatera drugoplanowego) muzyk z Jamajki. Nieco starszą młodzież może zainteresować powieść Do pierwszej krwi (2006) Grzegorza Gortata, obrazująca życie wietnamskich imigrantów w Warszawie, oraz Zupa z jeża (2012) Magdaleny Kozłowskiej, poświęcona polskim Romom.

Podobnie jak w przypadku książek dla przedszkolaków, także i te adresowane są do czytelnika polskiego. Daje się jednak zauważyć większe zróżnicowanie perspektywy narracji - o ile pierwsze trzy pozycje powtarzają wcześniej omówiony schemat narracji pamiętnikarskiej (polskie dziecko spotyka się z odmiennością w swoim środowisku), to u Kozłowskiej rolę narratora pierwszoosobowego przejmuje romska dziewczyna mieszkająca w Polsce, a w powieści Gortata występuje trzecioosobowa narracja autorska. Autorzy powyższych książek śmielej mówią o nietolerancji i problemach w relacjach między społecznością polską a przedstawicielem obcej narodowości. Choć generalnie „obcy” spotykają się z pozytywnym przyjęciem, odnajdują przyjaźń i miłość, to wszystkie wymienione powieści opisują także przykłady braku akceptacji i przemocy słownej, a aż cztery na pięć również fizyczną agresję motywowaną ksenofobią.

Autorzy omawianych powieści dbają o zachowanie autentyczności kulturowej, wykorzystując ją, by odwołać się do emocji czytelnika. Gortat wspomina o trudnej sytuacji w Wietnamie, prześladowaniu i okaleczaniu niepokornych obywateli, rozdzielaniu rodzin, wywołując współczucie. Z kolei bohaterzy Musierowicz 
i Szczepańskiej-Kowalczuk budzą sympatię i rozśmieszają przez swój charakterystyczny sposób wysławiania się, wynikający z niedoskonałego opanowania języka polskiego. Z wyjątkiem Zupy z jeża i Szczekającej szczęki Saszy, sygnały odmienności kulturowej mają epizodyczny, marginalny charakter i ograniczają się do imion, kulinariów czy wzmianek o sytuacji politycznej w kraju pochodzenia „obcego” bohatera; podobnie jest z odwołaniami do stereotypów - autorzy budują narrację wokół relacji swój-obcy, opisując konflikt i brak tolerancji, jednak bez odniesień do uproszczonych obrazów przedstawicieli konkretnych narodowości.

Dogłębną analizę odmienności kulturowej w kontekście narodowo-etnicznym znajdziemy zaledwie w dwóch książkach - powieściach autorstwa Grętkiewicz i Kozłowskiej, które ze względu na wielowymiarowość opisu zostaną omówione osobno.

Szczekajq̨ca szczęka Saszy opisuje roczny pobyt Saszy, Białorusina o polskich korzeniach, w polskiej szkole podstawowej. Problem odmienności głównego bohatera opisany jest dość szczegółowo, z perspektywy jego kuzynki. Przedmiotem drwin kolegów z klasy i przezwisk jest nie tylko charakterystyczny akcent Saszy, ale i jego status materialny, ogólnie odzwierciedlający różnice w przeciętnej zamożności Polaków i Białorusinów. Sam bohater mówi: „A u nas ludzie biedniej żyją. [...] Macie wszystko w sklepach, a takie ciuchy, że u nas tylko same bogate mogą kupić, ale cieszyć się nie umiecie. U nas życie cięższe, ale ludzie weselsze” Grętkiewicz, 2005, s. 128). Sasza boleśnie przeżywa odrzucenie, tym bardziej, że przyjechał do Polski motywowany przede wszystkim ciekawością innej kultury. Podsumowując swoje doświadczenia za granicą, mówi: „Jakby do mojej szkoły ktoś z Polski przyjechał, toby wszystkie byli ciekawe, co on za jeden. A nie tylko wyśmiewali, że nie po naszemu mówi, innej muzyki słuszajet” (Grętkiewicz, 2005, s. 128).

Szkolna codzienność, odrzucenie i upokorzenie przez społeczność polską stanowią także przedmiot refleksji w Zupie z jeża. Powieść dotyczy Romów, „rodzimych obcych” (por. Janus-Sitarz 2014, s. 21), mimo wielowiekowej współegzystencji z Polakami oddzielonych od nich „nieprzekraczalnym dystansem społecznym” i stanowiących najmniej lubianą grupę narodowo-etniczną (Grzymała, 2007, s. 233). Fabuła przedstawia wydarzenia z teraźniejszości, czyli podpalenie kamienicy, w której mieszkają Cyganie, przez nastoletnich sąsiadów, jako tło dla historii z przeszłości opowiadanych przez babcię narratorki, 13-letniej Jaelle. Właściwie historia rodziny głównej bohaterki jest pretekstem do ukazania historii Romów, zarówno z jej radosnymi, jak i tragicznymi momentami. Na tle omawianych wcześniej w artykule książek, Zupa z jeża wyróżnia się przede wszystkim obszernym, wielowymiarowym przedstawieniem realiów kulturowych 
na wielu poziomach: od języka i specyficznych sformułowań, poprzez opisane szczegółowo aspekty codziennego życia społeczności romskiej, aż po odwołania do historii ludu. Autorka uwzględniła wierzenia Romów, dotyczące m.in. poglądów na relacje między światem żywych i umarłych; przedstawiła też zjawiska nadprzyrodzone - kobiety z rodziny Jaelle posiadają zdolność „widzenia”, co wyróżnia je na tle innych romskich kobiet zajmujących się wróżeniem. Z racji wzmianek o magii książka może być uznana za kontrowersyjną, podobnie jak miało to miejsce w przypadku serii o Harrym Potterze. W powieści zwraca uwagę także perspektywa narratora, którym jest przedstawiciel odmiennej społeczności. Dzięki opowieściom Jaelle i jej babki czytelnik poznaje cygańskie spojrzenie na świat. I tak na przykład, kultura romska kładzie duży nacisk na rozdzielenie świata kobiet i świata mężczyzn, czego przejawem jest oddzielne pranie rzeczy należących do obu płci czy osobne spożywanie posiłków (wspólny posiłek zostałby uznany za brak szacunku kobiet do mężczyzn). W książce roi się od podobnych informacji, wyjaśniających różnice między obiema kulturami. Kolejnym czynnikiem wyróżniającym powieść Kozłowskiej na tle innych jest fakt, że zaprezentowano wewnętrzne życie całej społeczności, a nie tylko pojedynczych osób czy rodzin. Dzięki temu możliwe jest niezwykle realistyczne opisanie przeżyć bohaterki, takich jak problem braku wspólnego języka z rówieśnikami, poczucie wyobcowania i zagubienia oraz rozdwojenie między skrajnie różnymi oczekiwaniami otoczenia.

W obu historiach znajdziemy fragmenty w zabawny sposób kwestionujące stereotypowe przedstawienia Ukraińców i Cyganów. Na wieść o przyjeździe Saszy, mama kuzynki natychmiast zabiera się do lepienia pierogów: „-- Nie wiesz, córeczko, że na Białorusi bardzo lubią pierogi? - To czemu ma je jeść jeszcze u nas? - zdziwiła się Sylwia. - Może będzie wolał hamburgery z keczupem i frytki?” (Grętkiewicz, 2005, s. 17). I rzeczywiście - na widok odgrzewanych pierogów Sasza bynajmniej nie wpada w zachwyt: „-- Oj, ciocia Kaja to tak jak ciocia Teresa, nic tylko pierogi! Jak nie z grzybami, to z mięsem, jak nie z mięsem, to z kapustą. A latom z cziornymi ja... jagodami albo z wiszniami” (Grętkiewicz, 2005, s. 21). Z podobnym stereotypowym spojrzeniem na inność konfrontowany jest czytelnik drugiej z omawianych powieści. Gdy Marta, koleżanka Jaelle, domaga się wróżby w sprawach miłosnych, ta odmawia, gdyż nie potrafi. „-- Wszystkie Cyganki potrafią - brutalnie uświadomiła jej Marta. Po raz kolejny okazało się, że wszyscy dookoła lepiej niż ona wiedzieli, co to znaczy być Cyganem. [...] Powinnaś zacząć tak: 'dobra pani... nieszczęście do pani się zbliża, Cyganka je widzi, pomogę go uniknąć, daj powróżyć Cygaaance...' - zaśpiewała [Marta]. Po chwili znudziła się zabawą” (Kozłowska, 2012, s. 73). Autorka próbuje zmierzyć się także z innym stereotypem - Cygana jako złodzieja (por. skojarzenia językowe - 
cyganić, wycyganić). Powieściowi Romowie, zakorzenieni w swoistym systemie wartości, traktują zabranie czyjejś własności w odmiennych kategoriach - jest ono warunkiem przetrwania, dowodem sprytu i oznaką szczęścia: „z wypraw przynosił cenne zdobycze, bo i sprytu miał co niemiara”, (Kozłowska, 2012, s. 146); „szykowałam gęste polewki z kury, gdy udało nam się jakąś upolować z cudzego kurnika”, (Kozłowska, 2012, s. 82). Dzięki takim fragmentom czytelnik ma szansę skonfrontować się z powszechnie funkcjonującym w świadomości społecznej uproszczonym obrazem przedstawicieli odmiennych kultur i zdystansować się wobec stereotypu.

Zarówno Grętkiewicz, jak i Kozłowska kreują swoich bohaterów na postaci pełnowymiarowe, wykraczające poza stereotypy, aktywne i sterujące własnym losem, poszukujące swojego miejsca między dwiema kulturami. O ile pierwsza historia kończy się wejściem w dialog i zrozumieniem obu stron, ukazując wartość odmienności jako wzajemnego ubogacenia, to przesłaniem drugiej jest podkreślenie nieprzystawalności świata Romów i świata gadziów. Metaforą niemożności pogodzenia obu stylów życia są dwa małżeństwa - babki Jaelle, która zerwała ze swoją rodziną, by wyjść za Polaka, oraz Polki, która przez małżeństwo weszła w społeczność romską. Oba związki zakończyły się tragicznie i zostały porównane do próby pogodzenia ognia z wodą, w wyniku której „można tylko uzyskać dużo dymu, a potem garść popiołu zaledwie...” (Kozłowska, 2012, s. 166).

W jaki sposób obie powieści mogą zostać wykorzystane do celów edukacji międzykulturowej? Z pewnością nie propagują asymilacji ze społecznością dominującą (w tym przypadku polską), co byłoby typowe dla nacechowanego ideologicznie podejścia wielokulturowego. Zachęcają za to do poznania odmienności i docenienia jej, wyzbywania się poczucia wyższości kulturowej i uprzedzeń w kontakcie z Innym. Podkreślają też wartość wzajemnego poszanowania i dialogu, wskazując jednocześnie, że nie zawsze będzie możliwe osiągnięcie pełnego porozumienia i pogodzenie nierzadko sprzecznych wartości.

\section{KONKLUZJE}

Wydaje się, że rola literatury w kształtowaniu postawy otwartości wobec odmienności narodowo-etnicznej jest w naszym kraju niedoceniana. Na podstawie przeanalizowanego materiału można stwierdzić, że najliczniej występujące w Polsce mniejszości (głównie niemiecka, ukraińska i inne) nie są w ogóle obecne w najnowszej literaturze dla młodego odbiorcy. Opisywani są głównie przybysze z krajów azjatyckich i afrykańskich (w ośmiu z jedenastu książek). Co ciekawe, 
zwłaszcza w pozycjach przeznaczonych dla młodszych czytelników, najczęściej reprezentowane są mniejszości najmniej liczne, za to najbardziej egzotyczne (o innym kolorze skóry) i być może dlatego wzbudzające największe zainteresowanie. Taki wybór przedstawicieli omawianych narodowości prawdopodobnie dobrze służy celom początkowej edukacji międzykulturowej, której zadaniem jest uświadomienie istnienia samego zjawiska zróżnicowania kulturowego, by dopiero na takiej podstawie budować postawę otwartości wobec Innego. Co ciekawe, podczas gdy książki dla młodszych dzieci przedstawiają obcość w sposób uproszczony, głównie za pomocą odwołań do zewnętrznych jej przejawów, takich jak język czy kolor skóry, to już książki dla dzieci w wieku szkolnym podchodzą do tego tematu w sposób bardziej kompleksowy, zwracając większą uwagę na odmienność uwidaczniającą się w zachowaniu, sposobie spojrzenia na świat, wyznawanym systemie wartości. Zarówno w literaturze dziecięcej, jak i młodzieżowej kwestionuje się istniejące stereotypy, podchodząc do nich w krytyczny, często humorystyczny sposób.

W analizowanych książkach (z jednym wyjątkiem, który stanowi powieść Kozłowskiej) zwraca uwagę brak spojrzenia od wewnątrz danej społeczności, co sprzyjałoby identyfikacji z bohaterem i umożliwiało ogląd rzeczywistości z jego perspektywy. We wszystkich innych przypadkach mamy do czynienia z perspektywą dziecka/nastolatka polskiego stykającego się z odmiennością w swoim środowisku. Przekłada się to na sylwetkę zamierzonego odbiorcy, którym w analizowanych pozycjach było zawsze dziecko polskie.

Jeśli chodzi o relacje między bohaterami odmiennymi kulturowo, to można wyróżnić cztery główne schematy ich opisu. Piątkowska i Gawryluk (2013) w książkach kierowanych do najmłodszych dzieci przedstawiają jednostronny, pozytywny stosunek społeczności polskiej wobec odmienności, nacechowany ciekawością i chęcią poznania tego, co nowe. Odwrotną sytuację znajdziemy u Kozłowskiej - Romowie to „odwieczni obcy”, którzy muszą pozostać na marginesie społeczeństwa. Książki Musierowicz, Gawryluk (2009) i Kasdepkego kreślą ambiwalentny stosunek społeczności przyjmującej, w której obcy spotyka się z sympatią większości, jednak okazjonalnie także z niechęcią czy agresją ze strony jednostek. W pozostałych pozycjach zaprezentowana jest wewnętrzna przemiana bohatera i ewolucja jego nastawienia wobec odmienności - początkowa niechęć przeradza się w przyjaźń.

Co ciekawe, stereotypy odnoszące się do konkretnych narodowości znajdziemy tylko u Gortata, Grętkiewicz, Kasdepkego, Kozłowskiej i Pruchnickiej. Ich zgodność z rzeczywistością została jednak we wszystkich przypadkach zakwestionowana, a same stereotypy - ośmieszone. Choć wszyscy autorzy podjęli wysiłek 
jak najbardziej autentycznego przedstawienia danej kultury, to ze względu na specyfikę literatury dziecięcej i młodzieżowej nie zawsze było możliwe zachowanie wielowymiarowości opisu. Poszczególne powieści czy zbiory opowiadań w bardzo różnym stopniu spełniają to ostatnie kryterium - od Przedszkolaków z ulicy Morelowej, gdzie obcość jest zasygnalizowana w kilku zaledwie zdaniach, po Zupę z jeża, stanowiącą kompleksowe studium odmienności kulturowej.

W swojej charakterystyce optymalnego modelu pedagogii międzykulturowej Xavier Cuillard (1981) podkreśla, że „powinna ona przede wszystkim doprowadzić środowisko szkolne i pozaszkolne dziecka do uznania jego istnienia oraz wzięcia pod uwagę nie tyle jego odmienności, co potencjalnego bogactwa, zarówno językowego, jak i kulturowego, wypływającego z kultury pochodzenia dziecka” (cytat za: Grzybowski, 2008, s. 71). Wydaje się, że większość analizowanych pozycji w ten model się wpisuje, afirmując różnorodność i tolerancję, a jednocześnie zapobiegając bezkrytycznemu przejmowaniu i powielaniu stereotypów. Podchodząc bez uprzedzeń do przedstawicieli odmiennej kultury, czytelnik ma szansę utożsamić „inność” z nowością, a nie obcością (por. Kamińska, 2005, s. 22), przechodząc od schematu Inny - Obcy - Wróg do schematu Inny - Interesujący - Przyjaciel. Należy jednak pamiętać o tym, by kształtując postawę otwartości nie zaniedbywać kształtowania pewnego wyczucia potencjalnie niebezpiecznych sytuacji, w których stroną może być osoba odmienna kulturowo. W niektórych kontekstach stereotypowe ujęcie może mieć wymiar „ochronny”, uczący ostrożności, zwłaszcza w drażliwych sytuacjach, gdy kultury wyznają przeciwstawne wartości lub gdy druga strona nie jest przygotowana do prowadzenia dialogu.

Na podstawie powyższej analizy można stwierdzić, że odmienność w wymiarze narodowo-etnicznym nie jest (jeszcze?) ważnym problemem w polskiej literaturze dziecięcej, wobec czego tylko w ograniczonym stopniu może ona stać się częścią edukacji międzykulturowej. Co ciekawe, taka sytuacja nie jest niczym nowym. Już w roku 1996 Joanna Papuzińska, analizując stereotypy narodowościowe w polskiej literaturze dziecięcej okresu zaborów, II Rzeczpospolitej i PRL, podkreślała „zubożenie refleksji nad współżyciem różnych kultur na jednym terytorium” oraz wielką lukę „w świadomości młodych pokoleń Polaków na temat najbliższych sąsiadów i współmieszkańców” (Papuzińska, 1996, s. 111). Również Kamińska (2005, s. 62) w swojej analizie dotyczącej polskiej prozy lat dziewięćdziesiątych zauważa, że „trudno [...] znaleźć chociaż namiastkę problematyki dotyczącej odmienności kulturowej tak w odniesieniu do dziecka o niepolskim rodowodzie, któremu przyszło żyć wśród polskich rówieśników, jak i dziecka wywodzącego się z mniejszości narodowej, a jednocześnie pisanej z myślą o małym dziecku”. Niniejszy artykuł wypada zakończyć podobną refleksją, chociaż da się zauważyć 
drobne zmiany na lepsze - są autorzy, którzy coraz chętniej podejmują temat odmienności kulturowej. I dobrze, ponieważ nie ulega wątpliwości, że warunkiem atrakcyjności literatury jest to, na ile odbija ona rzeczywisty, współczesny świat, a wielość kultur jest jego nieodłączną cechą. Z całą pewnością, by ponownie odwołać się do diagnozy Joanny Papuzińskiej, „współczesna literatura dziecięca ma przed sobą bardzo ciekawy obszar do penetracji” (Papuzińska, 1996, s. 111).

\section{Literatura:}

Literatura dziecięca i młodzieżowa:

Gawryluk, B. (2009). Zuzanka z pistacjowego domu. Łódź: Wydawnictwo Literatura.

Gawryluk, B. (2013/2005). Przedszkolaki z ulicy Morelowej. Łódź: Literatura.

Gortat, G. (2006). Do pierwszej krwi. Wrocław: Zakład Narodowy im. Ossolińskich.

Grętkiewicz, E. (2005). Szczekająca szczęka Saszy. Warszawa: Nasza Księgarnia.

Kasdepke, G. (2013/2008). Kacper z szuflady. Łódź: Wydawnictwo Literatura.

Kozłowska, M. (2012). Zupa z jeża. Gdynia: Novae Res.

Musierowicz, M. (2004). Język Trolli. Łódź: Akapit Press.

Piątkowska, R. (2015/2006). Opowiadania z piaskownicy. Warszawa: bis.

Pruchnicka, K. (2015). Nowa w przedszkolu. Warszawa: Muza.

Stanecka, Z. (2011). Basia i kolega z Haiti. Warszawa: Literacki Egmont.

Szczepańska-Kowalczuk, K. (2009). Majka, Marcel i afrykańskie czary. Kraków: Społeczny Instytut Wydawniczy Znak.

Literatura przedmiotu:

Botelho, M.J., Kabakow Rudman, M. (2009). Critical multicultural analysis of children's literature. Mirrors, windows, and doors. London, New York: Routledge.

Cai, M., Bishop, R.S. (1994). Multicultural literature for children: Towards a clarification of the concept. W: A.H. Dyson, C. Genishi (red.), The need for story: Cultural diversity in classroom and community. Urbana, IL: NCTE.

Cuillard, X. (1981). De la „culture d'origine” et de la „pedagogie interculturelle”. Paris.

Grzybowski, P. (2008). Edukacja międzykulturowa - przewodnik. Pojęcia - literatura adresy. Kraków: Impuls.

Grzymała, A. (2007). Konstruowanie „innego”. Wizerunki imigrantów w Polsce. Warszawa: Wydawnictwa Uniwersytetu Warszawskiego.

Janus-Sitarz, A. (2014). Edukacja literacka wobec dylematów wielokulturowości i inności. W: A. Janus-Sitarz (red.), Edukacja polonistyczna wobec Innego. Kraków: Universitas.

Kamińska, K. (2005). W stronę wielokulturowości w edukacji przedszkolnej. Warszawa: Wydawnictwa Szkolne i Pedagogiczne.

Larrick, N. (1965). The All-White World of Children's Books. The Saturday Review, September 11, s. 63-65. Pobrane z: https://www.unz.org/Pub/SaturdayRev-1965sep11-00063. 
Niesporek-Szamburska, B., Wójcik-Dudek, M. (2014). Wyczytać świat - międzykulturowość w literaturze dla dzieci i młodzieży. Katowice: Wydawnictwo Uniwersytetu Śląskiego.

Papuzińska, J. (1996). My i Oni, czyli stereotypy narodowe w polskiej literaturze dziecięcej. W: J. Papuzińska (red.), Dziecko w świecie emocji literackich. Warszawa: SBP.

Pratt, L. (1999). Transcultural children's literature. Upper Saddle River, N.J.: Merrill. Shavit, Z. (1994). Poetics of children's literature. Athens, London: University of Georgia Press.

Short, K., Lynch-Brown, C., Tomlinson, C.M. (2014). Essentials of children's literature. Boston i in.: Pearson.

Struktura narodowo-etniczna, językowa i wyznaniowa ludności Polski - NSP 2011. (2015). Warszawa: GUS. Pobrane z: http://stat.gov.pl/spisy-powszechne/nsp-2011/ nsp-2011-wyniki/struktura-narodowo-etniczna-jezykowa-i-wyznaniowa-ludnoscipolski-nsp-2011,22,1.html.

Wróblewska, V. (2013). „Duch inności” w prozie dla młodego odbiorcy Janusza Korczaka. W: A.M. Czernow (red.), Janusz Korczak. Pisarz. Warszawa: SBP. 